\title{
PROJECT MANAGER LEADERSHIP BEHAVIOR: TASK-ORIENTED VERSUS RELATIONSHIP-ORIENTED
}

\section{Abstract}

In this paper, we examined managers' leadership behavior when working on a simulated team project regarding task-oriented versus relationship-oriented leadership behavior to effectively achieve successful project completion. Managers attending an advanced project management development program responded to the Fielder Leadership Behavior Style Self-Assessment, which is a useful framework to determine task-oriented versus relationship-oriented leadership behavioral styles. The degree of task-oriented versus relationshiporiented leadership behavior styles was assessed to determine the approach taken by the managers for achieving successful project completion. A Pearson's chi-square test was conducted to determine whether the observed values were significantly different from an expected value of five. The findings can contribute to better understanding the leadership styles, which characterize project management accomplishment.

\section{Introduction}

Project managers fulfill numerous roles to achieve completion of projects within the triple constraints of scope, time, and budget, as well as meeting the quality requirements of the project's objectives and stakeholders' expectations. To accomplish project completion success, project managers must have a good understanding of how to apply the tools and techniques of quality project management (Anderson, 1992; PmBOK, 2017). However, project management is more than applying the technical skills of doing the project work by using specific knowledge, methods, and techniques, such as planning, scheduling, budgeting, and computing, and working with numbers, templates, charts, and graphs. Crucially, project managers, project managers must lead the project team members, interact efficiently, and influence other stakeholders (Hardy-Vallee, 2012; Kumar, 2009).
Therefore, there is a wide range of interpersonal skills that a project manager must develop and learn to use at the appropriate time; these skills include leadership, communication, organization, team-building, coping, risk management, conflict, planning, administration, resource allocation, and change management skills (Kerzner, 2001; Pinto \& Trialer, 1998; Stine, 2018). One of these key interpersonal skills is leadership, which, undoubtedly, project managers must master to complete projects within the triple constraints of scope, schedule, and budget during the project life cycle (Muzio, Fisher, Thomas, \& Peters, 2007; Jones, 2018). Additionally, project managers' understanding of their leadership behavioral style and ability to predict a team member's readiness for the work are crucial in leading people and projects to success (Arora \& Baronikian, 2013).

We began our research by accepting the premise that 
a large part of a project manager's role is guiding, motivating, and leading a project team (Schmid \& Adams, 2008). As a result, organizations should designate project managers who are proactive and able to lead projects to successful completion (PmBOK, 2017). In this study, we specifically deliberated the advantages and limitations of two project manager leadership behavioral styles: taskoriented leadership versus relationship-oriented leadership. The first, task-oriented leadership behavior, relates to the extent to which the leader engages in determining where the project should be completed and who should comprise the project team. Conversely, relationship-oriented leadership behavior is the extent to which a leader engages successfully in complex communication scenarios (Fiedler, 1967). While significant evidence describes the organizational factors underpinning the need for effective leadership for successful project completion, it remains that very little is known about what type of leadership behavior style a project manager should employ or which is best for project success.

To provide contextual focus to our research, we explored both task leadership behavior and relationship leadership behavior to determine how they relate to the effectiveness of project managers in leading project teams for successful project completion. We also focused on the use of both of these leadership behavioral styles, specifically concentrating on the potential to lead the complete life cycle of a project to completion, which could include both work breakdown and interpersonal interactions. Our decision to pursue this focus is aimed at providing a meaningful, practical extension of existing thought on related project manager leadership behaviors. It is also designed to allow for the re-examination of standing theoretical assumptions regarding the applicability of leadership behavioral styles within the typical context of leading project teams in a leadership educational setting.

\section{Literature Review}

Early researchers endeavored to answer the question: are leaders born or made? (Amanchukwu, Stanley, \& Ololube, 2015). Or, more specifically, do leaders have certain distinctive characteristics such as intelligence, honesty, self-confidence, appearance, or energy? After years of research, the leadership trait theory failed to produce a list of key leadership traits needed for success (Lewis, 2003). In the early 1950s, researchers shifted from the trait theory to behavioral theories, which focus on what the leader does (Ambler, 2017; Fernandez, 2008; Yukl, 2010). A leadership study that served as a forerunner to the leadership behavior approach was the University of lowa study conducted by Kurt Lewin and associates, which recognized two basic leadership styles. One is the autocratic leader, who tends to lead by position of power, control of rewards, and coercion. The other is the democratic leader, who relies on encouraging employees to participate in decisions and respecting the employees' skills and knowledge (Lewin, Lippitt, \&White, 1939).

Moreover, research on how leaders functioned in small groups was conducted at the University of Michigan under the direction of Rensis Likert who developed a questionnaire to gather data on leadership styles. This research identified two primary leadership styles: job-centered (the degree to which the leader directly oversees the accomplishment of tasks) and employee-centered (the degree to which the leader focuses on employees and their needs) (Katz, Macoby, \& Morre, 1950; Katz, Macoby, \& Gurin, 1951). Around the same period, other leadership studies were conducted at the Ohio State University and focused on how leaders behaved when they were in charge of a work group or a work organization (Halpin, 1956; Stogdill, 1948). Based on the Ohio State University Leadership study, two wide-ranging classifications of leader behavior types emerged: consideration (the degree to which a leader exhibits concern for subordinates by acknowledging their 
ideas and feelings, enthusiastically working to ensure mutual trust, seeking their input, actively listening, consulting with them on important matters or problem-solving, expressing a clear willingness to accept suggestions, and treating them as equals) and initiating structure (the degree to which a leader exhibits task orientation by defining the subordinates' roles and tasks, directing their work activities toward goal achievement, ruling with an iron hand, criticizing poor work, emphasizing the importance of meeting deadlines, and offering new approaches to problems). According to the Ohio State Leadership Studies, a leader can display a high degree of both consideration and initiating structure, a low degree of both types, high consideration, and low initiating structure, or low consideration and high initiating structure behavior (Burkus, 2010; Hemphill \& Coons, 1957; Fernandez, 2008; Stogdill, 1950).

In 1951, Fred E. Fiedler developed leadership contingency theory, which states that a leader's efficacy is contingent, or dependent, on two elements: whether the leader is task-oriented or relationshiporiented. Leaders who are task-oriented tend to focus on details. They do not tend to commence with an action plan until they are completely content they have all the required information. Conversely, leaders who are relationship-oriented tend to focus on creating trust and respect, will listen to the followers' needs and are comfortable with developing an action-plan when they have the followers' inputs (Geoghegan \& Dulewicz, 2008). It has been reported that a leader's success can be attributed to how these two leadership styles are exhibited (Law, 2015; Yukl, 2012). During the life of a project, situations will differ, thus calling for diverse leadership styles or a combination of both task and relationship behaviors (Mulcahy, 2018; Turner \& Muller, 2005). A study by Tabernero, Chambel, and Curral (2009) examining the role of task-oriented versus relationship-oriented found that relationship-oriented behavior roles had a positive effect on cohesion among team members. Conversely, task-oriented behavior roles were seen by team members as having higher levels of task accomplishment. The results of the study are supportive of various other studies, reinforcing the importance of leadership behaviors in the workplace. The Bono, Foldes, Vinson, and Muros (2007) study adds to the importance of selecting the correct leadership style when interacting with team members. They found that employees experienced more positive emotions throughout the workday, including interactions with other stakeholders, when they worked for a supervisor practicing transformational leadership. Daniel Goldman (1998), in his studies, found that the most effective leaders are those who have a high degree of emotional intelligence to include self-awareness, self-regulation, motivation, empathy towards team members, and social skills.

Undoubtedly, a project manager must have the technical skills to manage the standard triangle of the deadline, scope, and cost to accomplish the goals and objectives of a project (Baratta, 2006). Increasingly, these demands mean providing the essential leadership required to ensure a successful project that meets stakeholders' quality expectations in a global marketplace where changes occur rapidly and dealing with different cultures is paramount (Lindblad, 2014). Therefore, we began our consideration of project manager leadership by accepting the premise that nowhere is the interpersonal skill of leadership more important than when managing an organization's project. Consequently, the success of a project relies on a project manager that has and applies leadership skills in both developing a high-performing project team and also leading the team to achieve the project's charter (Dow \& Taylor, 2015; Geoghegan \& Dulewicz, 2008). Task-oriented and relationshiporiented leadership behavioral styles have a positive effect on team performance (Tabernero, Chambel, Curral, \& Arana, 2009).

Since leadership is typically situational (Hersey, 2009; Hogg, van Knippenberg, \& Rasta, 2012), it may behoove project managers to apply different leadership styles during throughout the life cycle of a project (Mulcahy, 2018). However, to accomplish that goal, project managers must analyze the readiness of their project team members in terms of strengths and weaknesses (Snyder, 2012), and adjust their 
leadership styles based on the maturity, experience, and the needs of the project team members and the complexity of the project(s) being worked on (Burgan \& Burgan, 2014). Thus, examining the factors that determine successful leadership behaviors during the life cycle of a project becomes a critical element of this present study, providing insight into the needs of leadership education and training.

\section{Purpose of the Study}

Accomplishing successful project completion when leading a project team does not occur by accident (Frese \& Sauter, 2003). As faculty teaching project management leadership courses, we had observed that it is very common that when managers first entered the advanced project management leadership course, most of them believed that they were relationship-type leadership behavior managers. However, based on the literature review, it was clear that these managers should apply both task and relationship behavior-type leadership behaviors during the life cycle of a project. Thus, the following hypotheses were developed and evaluated. Therefore, in this paper, we aimed to gain an insight into the managers' task leadership behavior versus relationship leadership behavior applied when managing a simulated in-class team project and their self-assessment of the type of leadership they applied based on their completion of the Fred Fiedler Leadership Behavior Style Self-Assessment survey. We believe the managers responses to the survey can provide crucial evidence to assist in the development of effective leadership education applications.

\section{Hypotheses}

H10: Managers attending an advanced project management educational program did not exhibit high taskoriented leadership behavior style during a simulated in-class project as indicated in their leadership self-assessment scores.

H1a: Managers attending an advanced project management educational program did exhibit high task-oriented leadership behavior style during a simulated in-class project as indicated in their leadership self-assessment scores.

H20: Managers attending an advanced project management educational program did not exhibit high relationshiporiented leadership behavior style during a simulated in-class project as indicated in their leadership self-assessment scores.

H2a: Managers attending an advanced project management educational program did exhibit high relationshiporiented leadership behavior style during a simulated in-class project as indicated in their leadership self-assessment scores.

\section{Methodology}

Research. This study focused on a group of managers who attended an advanced project management educational program. As previously stated, successful project management includes balancing the traditional triangle of scope, time, and cost (Baratta, 2006). To accomplish project success, a project manager utilizes technical and strategic management skills but also applies the "soft skills" such as communicating effectively, motivating team members, making decisions, exhibiting appropriate conflict management strategies, possessing emotional intelligence, setting the vision, and leading project team members (Gehring, 2007). The key research questions in the present study are as follows:

1. What do managers attending an advanced project management leadership program report regarding task-oriented and relationshiporiented leadership behaviors applied during an in-class project life cycle?

2. Would understanding and applying taskoriented and relationship-oriented leadership behaviors act as an aid when establishing various project management leadership curricula, including courses and specific project management lesson plans? 
Data Collection. Experienced managers who attended an advanced project management master's degree educational degree program were requested to complete the Fred Fielder leadership behavioral style self-assessment survey (Lussier \& Achua, 2016) to determine their preferred task or relationship leadership behavioral styles when leading a team in a simulated in-class project. The managers surveyed were attending a largesized university with campuses in the USA and at several international locations. During a twoyear period, a total of 129 managers in several classes and who worked in various industries and organizations worldwide responded to the selfassessment questionnaire. There were 88 male and 41 female experienced manager respondents. The respondents' privacy and confidentiality were strictly protected.

Task and Procedure. Our research study was conducted as part of an advanced project management educational program, and attending managers were assigned a simulated in-class project to lead effectively. Based on their experience with the in-class simulated project, these managers answered a Fielder self-assessment questionnaire about their leadership behavioral style used when leading a project to successful completion. The self-assessment survey contained 20 questions and was administered as a classroom exercise. For each of the 20 questions, the managers would place a 1 if they would engage in that leadership behavior and a 0 if they would not. They would then place the $1 \mathrm{~s}$ and $0 \mathrm{~s}$ on a scale of 1 to 10 for each of the leadership behavior styles (Lussier \& Achua, 2016). A significant finding would suggest whether the managers' leadership behaviors styles would tend to

Table 1.

High Task Leadership data analysis responses.

\begin{tabular}{|l|c|}
\hline \multicolumn{2}{|c|}{ High Task } \\
\hline \hline Mean & 7.11 \\
\hline Median & 7 \\
\hline Mode & 9 \\
\hline Standard Deviation & 2.25 \\
\hline Count & 129 \\
\hline
\end{tabular}

be overall, task-oriented or relationship-oriented in their leadership style when managing projects.

Statistical Measures. We gathered descriptive statistics, and then we used the Pearson chi-square test to determine whether there was a significant difference between the expected frequencies and the observed frequencies in either task-oriented leadership behavior or relationship-oriented leadership behavior. We wanted to test whether attending the advanced project management course and leading an in-class project team influence how managers used task-related leadership versus relationship-related leadership based on their leadership self-assessment scores. The Pearson chisquare provided a richness of detail, which allowed us to understand the results and thus derive more detailed information than we could get from many other statistics (McHugh, 2013). A significant finding would suggest whether the managers' leadership behaviors styles would tend to be overall, taskoriented or relationship-oriented in their leadership style when managing projects.

\section{Research Results}

High Task Leadership Behavioral Data Analysis.

Descriptive Statistics. From inspection of the descriptive statistics in Table 1, it is evident that the mean is greater than the midpoint (a score of 5), and the most common score (mode) was 9. A midpoint score on the assessment is indicative of a leadership behavioral style that is neither high-task nor highrelationship-oriented. Scores trending much higher than the midpoint are indicative of a high-task orientation. No significant differences were found between the variables related to gender. 
Frequency Analysis-High Task Leadership Behavioral Style. The overall distribution of scores is provided in the frequency analysis chart. From inspection, the majority of scores exceeded the midpoint.

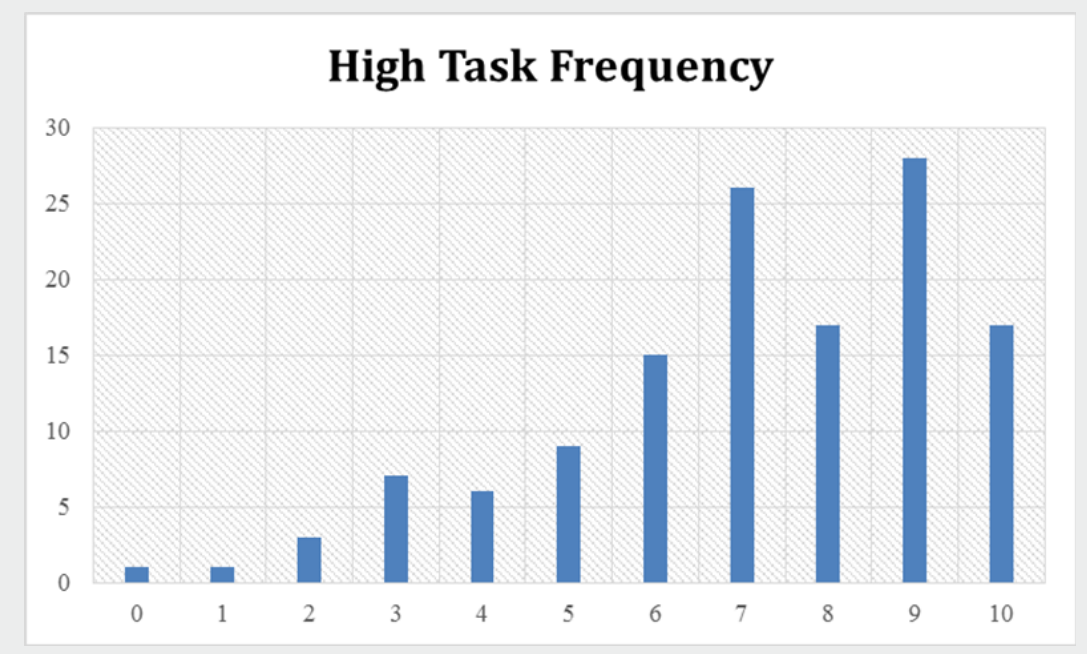

Figure 1. Frequency Analysis High-Task Leadership Behavior Ranked Responses

The Significance of High-Task Leadership Scores. A scores differ substantially from the midpoint scores. clear pattern is observed in the descriptive statistics A pattern of scores that differ from the midpoint and frequency analysis. It is of interest to determine is indicative of a significant trend in leadership whether the majority of leadership assessment behavioral styles of project management students.

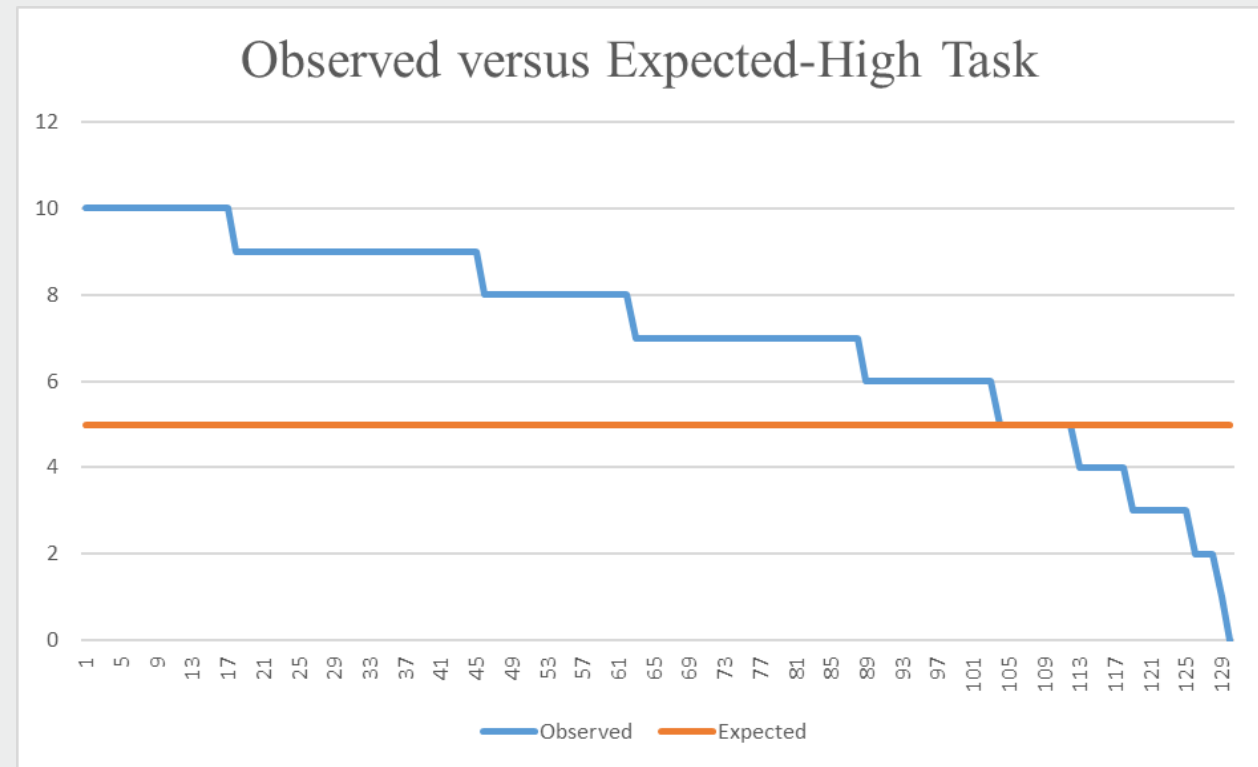

Figure 2. Observed versus Expected High-Task Leadership Responses 
The Chi-square Statistic. A Pearson's chi-square goodness of fit test was conducted to determine whether the observed values were significantly different from an expected value of five. With a $p$-value $<.001$, the differences were determined to be significant. The Pearson's chi-square goodness of fit test leads to the rejection of $\mathrm{H} 10$ and the acceptance of H1a (Minitab, 2013). The results indicate a significant pattern of high-task oriented leadership behavioral style among managers attending the advanced project management leadership program.

Table 2.

High Relationship Leader Data Analysis Responses.
High Relationship Leadership Behavioral Data Analysis.

Descriptive Statistics. From inspection of the descriptive statistics in Table 2, it is evident that the mean is greater than the midpoint (a score of 8.4), and the most common score (mode) was 10. A midpoint score on the assessment is indicative of a leadership style that is neither high task nor high relationship-oriented. Scores trending much higher than the midpoint are indicative of a highrelationship orientation.

\begin{tabular}{|l|r|}
\multicolumn{2}{|c|}{ High Relationship } \\
\hline \hline Mean & 8.40 \\
\hline Median & 9 \\
\hline Mode & 10 \\
\hline Standard Deviation & 2.63 \\
\hline Count & 129 \\
\hline
\end{tabular}

Frequency High Relationship-Type Leadership Style

The overall distribution of scores is provided in the frequency analysis chart. From inspection, the majority of the scores exceeded the midpoint. Consistent with the method used to assess high-task leadership orientation, it is of interest to determine if the majority of leadership assessment scores differ substantially from the midpoint scores. A pattern of scores that differ from the midpoint is indicative of a significant trend in the leadership behavioral style of project management students.

\section{Frequency-High Relationship}



Figure 3. Frequency High-Relationship Ranked Responses 
The Significance of High-Relationship Leadership Scores. A clear pattern is observed in the descriptive statistics and frequency analysis. The degree to which the scores are above the mid-point is of interest. The data is presented graphically as follows:

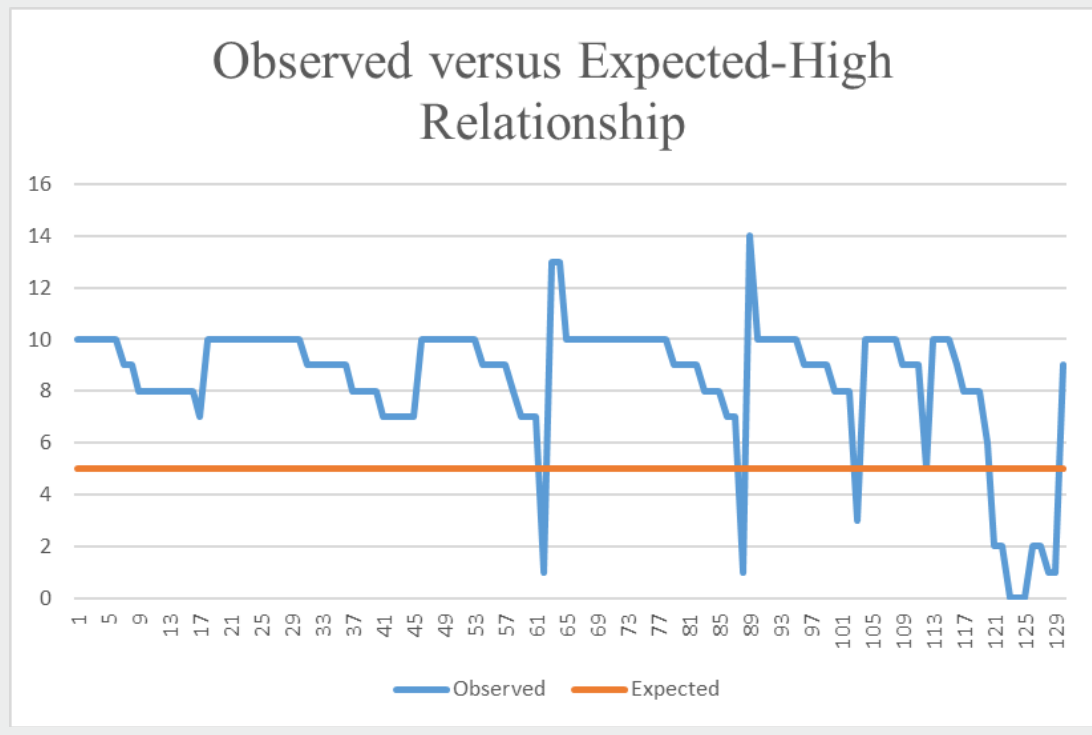

Figure 4. Observed versus Expected High-Relationship Leadership Responses

The Chi-square Statistic. A Pearson's chi-square goodness of fit test was conducted to determine if the observed values were significantly different from an expected value of five. With a $p$-value was less than .001, the differences were determined to be significant. The Pearson's chi-square goodness of fit test leads to the rejection of H2O and the acceptance of $\mathrm{H} 2 \mathrm{a}$ (Minitab, 2013). The results indicate a significant pattern of high-relationship oriented leadership behavioral style among the managers attending the advanced project management program.

\section{Discussion}

The importance of a project manager to be able to motivate and lead team members has well been established (Mulcahy, 2018; PmBOK, 2017; Schmid \& Adams, 2008). Concerning the emergent leadership behavioral styles used by managers in this present study to lead team project interactions, the results revealed that both task-oriented and relationshiporiented leadership type behaviors were used during the project cycle. The effect of using a particular leadership behavior style depended on the stage of the project cycle. At the beginning of the project, a task-oriented leadership type behavior may be more appropriate for a project manager to use to provide more direction (i.e. a directing leadership style) because only the project manager knows the full extent of the work that must be done to plan the project successfully. Plus, it is likely that the team members' roles and responsibilities will have to be communicated, so there is a need for clear understanding of just what needs to be accomplished for project completion. During the execution process, the project manager may then switch to a more relationship-oriented leadership behavior that includes coaching, facilitating, and supporting the project team members to effectively understand and utilize each team member's unique talents (Mulchahy, 2018). A relationship-oriented leadership behavioral style will allow for a more agile project-based work environment, which means the team members can act quickly with the trust of the project manager (Farley, 2005). 
The results of this present research study generally support the findings of other studies, which have shown the significant role that project manager leadership styles play in successful project completion. For example, in studying leadership behaviors, the Ohio State researchers discovered that initiating structures (task) and considerations (relationship) were separate and distinct dimensions and that a person who scored on one did not necessarily get a low score on the other. Furthermore, leadership behavior could be described as any mix of these leadership behaviors (Burkus, 2010; Hemphill \& Coons, 1957; Fernandez, 2008; Stogdill, 1950). Similarly, studies tend to show that there is no best style of leadership, and effective project managers adapt their leadership behaviors to meet the needs of the project team members and particular environment (Krahn \& Hartman, 2006; Fielder, 1967; Hersey, 2009; Mulcahy, 2018). Moreover, The Situational Leadership Model ${ }^{\circledR}$ based on two behavioral categories, task-oriented and relationship-oriented leadership behavior was first described by Fred Fielder (1967). Managers who display a taskoriented leadership behavior tend to focus on details, giving direction, and prescribing the work to be completed. Conversely, managers who display a relationship-oriented leadership behavior try to create trust and respect for the employees/ team members allowing them to be part of project decisions (Rajbhandar, Rajbhandari \&, (2016). The Situational Leadership Model ${ }^{\circledR}$ provides a balance between a manager's task-oriented leadership behavior and his/her relationship-oriented leadership behavior based on the employees' or team's readiness level for a specific task (Hersey, 2009).

The present study results show that managers revealed that both task-oriented leadership and relationship-oriented leadership behaviors are appropriate during the life cycle of a project (Smith, 2018) and tend to be in-line with research conducted at the Center for Leadership Studies, which revealed that most leaders have a primary leadership style and a secondary leadership style that is used when influencing team members (Hersey, Blanchard $\&$ Johnson, 2015). Genuinely effective project managers should adapt to the needs of the project team members during a project's life cycle (Krahn \& Hartman, 2006; Murthy \& Sreenivas, 2017).

\section{Conclusions and Recommendations}

Our study shows the importance of a situational leadership approach for successful project completion instead of a one-type leadership approach in that the results revealed that the managers exhibited a distribution pattern of the task and relationship-oriented leadership behavior styles and not an either/or leadership behavior style as various previous studies indicated. Furthermore, the present research study outcomes will assist managers in adopting a more favorable attitude and an open-minded approach when seeking to understand their leadership behavioral style as it relates to project management.

Traditionally, educational institutions offering project management degrees, courses, or training focus on the "hard technical" project manager skills much more than the "soft" skills such as leadership. We argue that educational institutions offering project management degrees, courses, or training should take an approach to teach project management that includes an in-depth emphasis on leadership behavioral styles. However, it is first critical to understand how project managers perform when leading project teams. The results of the present research will give educational institutions insight into leadership types that may assist in developing project management leadership courses and training programs to allow students a better understanding of how their personality type fits project manager leadership responsibilities. Leadership styles and skills can be learned based on a high level of self-knowledge and self-awareness, which is a statistically significant element in 
connection with project success (Geoghegan \& Dulewicz, 2008; Stine, 2018).

A potential limitation of this research study is it was carried out in a simulated project classroom setting, which may not cover the realities of all aspects of an industrial environment that can include working with various international cultures. Also, data were all self-reported. A more robust study would include surveys of the team members to indicate their perceptions of the leader behaviors. Moreover, a larger sample size could be obtained via conducting a study at different project management education and training programs to compare the findings of our study related to task versus relationship leadership behavioral styles. If this other study's findings were shown to be consistent across educational and training settings, the validity of the results of our present study would be strengthened. Researchers may also wish to add a qualitative research component to the study that gives the respondents an opportunity for narrative comments that could enhance findings. Because leadership situations may change over time, future research could include longitudinal studies to capture the understanding of the long-term effects of task leadership behavior and relationship leadership behavior on a project's life-cycle.

The majority of managers in this current study responding to the Fielder Leadership Style selfassessment felt that the results were helpful to them in their work as project managers. For example, when performing the project, the team members wanted their leader to engage more in task-oriented behaviors (i.e., clarifying purpose, defining goals, setting direction, and training coaching at the beginning of the simulated in-class project). On the other hand, when the project cycle progressed, team members wanted the more relationship-oriented leadership behavior (i.e., listening, showing interest, consideration, and autonomy-delegation). Therefore, adaptability of a project manager is essential to using the most effective leadership behavior at the right time.
The trustworthiness and credibility of this study were established through peer debriefing with other faculty teaching in the project management educational program. In reviewing our research project results, these established face validity of the self-assessment results. Researching the different advanced project management classes over a twoyear period showed test-retest reliability.

In sum, project managers are hired to manage projects successfully under the triple constraints of scope, time, and cost (Baratta, 2006). Effective project manager technical skills are necessary for ensuring project success, but also just as vital is the project management leader's interpersonal skills, not the least of which is providing the ability to motivate, inspire, and lead the project team. Research such as that conducted in our study can provide a baseline that is essential to the development of project manager leadership curricula. Such a methodology not only provides important evidence regarding different leadership behaviors required throughout the life-cycle of a project in which leadership training and development are needed, but it also assists in helping project management instructors. Additionally, students may be more receptive to gaining the leadership behaviors required for project management success. There are some self-assessment tools available to allow project managers to assess their strengths and weaknesses and thus challenge their critical thinking regarding why they think they are strong or weak in areas of their leadership behavior style for project success. In concert, educational institutions can capitalize on establishing self-development goals for continually working to achieve an important and personal investment for project managers' leadership behaviors with a sustained focus on personal growth (Amanchukwu, Stanley, \& Ololube, 2015; Arora \& Baronikian, 2013). 


\section{References}

Amanchukwu, R., Stanley, G, \&, N. (2015). A review of leadership theories, principles, and styles and their relevance to eductation management. Management 5(1), 6-14. Retrieved from http://article.sapub. org/10.5923.j.mm.20150501.02.html

Ambler, G. (2017, January 22). Leaders are born, they're made. Leadership develops. [Blog post]. Retrieved from https://www.georgeambler.com/leaders-are-not-born-theyre-made-leadership-develops/

Anderson, S. D. (1992). Project quality and project managers. International Journal of Project Management. Guildford, 10(3), $138-143$

Arora, M. \& Baronikian, H. (2013). Leadership in project management (2nd ed). Canada: Leadership Publishing House.

Baratta, A. (2006). The triple constraint: a triple illusion. Paper presented at PMI ${ }^{\circledR}$ Global Congress 2006North America, Seattle, WA. Newtown Square, PA: Project Management Institute.

Bono, J., Foldes, H., Vinson, G., \& Muros, J. (2007). Workplace emotions: The role of supervision and leadership. Journal of Applied Psychology, 92(5), 1357-1367.

Burgan, S. C. \& Burgan, D. S. (2014). One size does not fit all: Choosing the right project approach. Paper presented at $\mathrm{PMI}^{\circledR}$ Global Congress 2014-North America, Phoenix, AZ. Newtown Square, PA: Project Management Institute.

Burkus, D. (2010, February 11). Style theory.[Blog post]. Retrieved fromhttps://davidburkus.com/2010/02/ style-theory/

Dow, W. \& Taylor, B. (2015). Project management communication tools (1st ed.). Dow Publishing LLC: Renton, WA.

Farley, J. (2005). Leadership in agile projects — what makes for success? Paper presented at PMI ${ }^{\circledR}$ Global Congress 2005-Asia Pacific, Singapore. Newtown Square, PA: Project Management Institute.

Fernandez, S. (2008). Examining the effects of leadership behavior on employee perceptions of performance and job satisfaction. Public Performance \& Management Review, 32(2), 175-205.

Fiedler, F. (1967). A theory of leadership effectiveness. New York: McGraw-Hill.

Frese, R. \& Sauter, V. (2003). Project success and failure: What is success, what is failure, and how can you improve your odds for success? Retrieved from http://www.umsl.edu/ sauterv/analysis/6840_f03_ papers/frese/

Geoghegan, L. \& Dulewicz, V. (2008). Do project managers' leadership competencies contribute to project success? Project Management Journal, 39(4), 58-67.

Gehring, D. R. (2007). Applying traits theory of leadership to project management. Project Management Journal, 38(1), 44-54.

Goldman, D. (1998, November-December). What makes a leader? Harvard Business Journal, 93-102 


\section{References}

Hapin, A. (1956, December). The behavior of leaders. Educational Leadership, 172-186, Retrieved from https://pdfs.semanticscholar.org/d847/e03e8f2bb9d7e93864aee1615d654a5abb1c.pdf

Hardy-Vallee, B. (2012). How to run a successful project. Retrieved from https://news.gallup.com/ businessjournal/152756/run-successful-project.aspx

Hemphill, J. \& Coons, A. (1957). Development of the Leader Behavior DescriptionQuestionnaire. In R. M. Stogdill and A. E. Coons (Eds.), Leader behavior: Its description and measurement. Columbus, OH: Bureau of Business Research, Ohio State University.

Hersey, P. (2009). Situational leaders. Leadership Excellence, 26(2), 12.

Hersey, P, Blanchard, K., \& Johnson, D. (2013). Management of organizational behavior - Leading human resources. Pearson Prentice Hall: Upper Saddle River, NJ:

Hogg, D., van Knippenberg, D., \& Rastra D. (2012). The social identity theory of leadership: Theoretical origins, research findings, and conceptual developments. European Review of Social Psychology, 23(1), 258-304.

Jones, E. (2018). Honing interpersonal skills for successful project delivery.[Blog post]. Retrieved from https://www.pm4ngos.org/2018/04/14/honing-interpersonal-skills-for-successful-project-delivery/

Kaltz, D., Macoby, N., \& Morse, N. (1950). Productivity, supervision, and morale in an office situation. Ann Arbor, MI: Institute for Social Research.

Kaltz, D., Macoby, N., \& Gurin, G. (1951). Productivity, supervision, and morale among railroad workers. Ann Arbor, Ml: Survey Research Center, University of Michigan.

Kerzner, H. (2009). Project management: A systems approach to planning, scheduling, and controlling. John Wiley \& Sons: Hoboken, NJ.

Krahn, J. \& Hartment, F. (2006). Effective project leadership: a combination of project manager skills and competencies in context. Paper presented at PMI ${ }^{\circledast}$ Research Conference: New Directions in Project Management, Montréal, Québec, Canada. Newtown Square, PA: Project Management Institute.

Kumar, V. S. (2009). Essential leadership skills for project managers. Paper presented at $\mathrm{PMI}^{\circledR} \mathrm{Global}$ Congress 2009—North America, Orlando, FL. Newtown Square, PA: Project Management Institute.

Law, M. (2015, January). Examing task and relationship-orinted leadership styles: an in-class application activity. Journal of Academic and Business Ethics, 10, 1-6.

Lewin, K., Lippit, R. \& White, R.K. (1939). Patterns of aggressive behavior in experimentally created social climates. Journal of Social Psychology, 10, 271-301.

Lewis, J. (2003). Project leadership. Mc-Graw-Hill Education: New York, NY.

Lindblad, M. (2014). Project manager skills \& personality characteristics. Retrieved from http://everydaylife. globalpost.com/project-manager-skills-personality-characteristics-13166.html 


\section{References}

Lussier, R. \& Achua, C. (2016). Leadership: Theory, application, \& skill development (6th ed.). South-Western: Mason, $\mathrm{OH}$.

McHugh, M. (2013). The Chi-square test of independence. Retrieved from https://www.ncbi.nlm.nih.gov/ pmc/articles/PMC3900058/

Minitab. (2013). Minitab statistical software. Retrieved from http://www.minitab.com/en-us/products/ minitab/

Mulcahy, R. (2018). PMP exam prep (9th ed.). RCM Publications Inc.: Minnetonka, MN.

Murthy, A.\& Sreenivs, S. (2017). Does people behavior impact projects? How? And what do we do about it? PM Times: Resources for Project Managers. Retrieved from https://www.projecttimes.com/articles/doespeople-behavior-impact-projects-how-and-what-do-we-do-about-it.html

Muzio, E., Fisher, D. J., Thomas, E. R., \& Peters, V. (2007). Soft skills quantification (SSQ) for project manager competencies: improved approach to incorporate uncertainty using Bayesian networks. Project Management Journal, 38(2), 30-38.

Nova, B., Landis, E., \& Haley, M. (2017). Leadership and its role in the success of project management. Journal of Leadership, Accountability and Ethics, 14(1), 73-78.

Pinto J.\&Trialer J, (1998). Leadership skills for project managers. Project Management Institute Headquarters: Newtown Square, PA.

PMBOK Guide. (2017). A guide to the project management body of knowledge (6th ed.). Newtown Square, PA: Project Management Institute.

Rajbhandari, M., Rajbhandari, S., \& Loock, C. (2016). Relations- and task-oriented behaviour of school leaders: Cases from primary schools in Finland. South African Journal of Childhood Education, 6(1), 1-10.

Stogdill, R. (1948). Personal factors associated with leadership: A survey of the literature. Journal of Psychology, 25, 35-71.

Stogdill, R. (1950). Leadership, membership, and organization. Psychological Bulletin, 47,1-14.

Schmit, B. \& Adams, J. (2008). Motivation in project management: the project manager's perspective. Project Management Journal, 39(2), 60-71.

Snyder, C. (2012). Manage to lead: Flexing your leadership style. Newtown Square, PA: Project Management Institute.

Sridhara, A. \& S. (2017). Does people behavior impact projects? How and what do we do about it? PM Times: Resources for Project Managers. Retrieved from https://www.projecttimes.com/articles/doespeople-behavior-impact-projects-how-and-what-do-we-do-about-it.html.

Stine, J. (2018). How self-awareness makes you a better manager. [Blog post]. Retrieved from https://www. extension.harvard.edu/professional-development/blog/how-self-awareness-makes-you-better-manager. 


\section{References}

Tabernero, C.; Curral, M, \& Arana, J. (2009) The role of task-oriented versus relationship-oriented leadership on normative contract and group performance. Social Behavior and Personality, 37(10),1391-104.

Turner, J. R. \& Müller, R. (2005). The project manager's leadership style as a success factor on projects: a literature review. Project Management Journal, 36(2), 49-61.

Yukl, G. (2012). Effective leadership behavior: What we know and what questions need more attention. Academy of Management Perspectives, 66-85.

Yukl, G. (2013). Leadership in organizations (8th ed.). Upper Saddle River, NJ: Prentice Hall. 